Écrits des Maîtres soufis 2. Trois traités de Baghdadî et Semnânî. Traduction et présentation de Stéphane Ruspoli. Corbey, Arfuyen, 2008, 190 p. (Les Carnets spirituels)

\title{
Ève Feuillebois-Piérunek
}

\section{(2) OpenEdition}

\section{Journals}

Édition électronique

URL : http://journals.openedition.org/abstractairanica/39726

DOI : 10.4000/abstractairanica.39726

ISSN : 1961-960X

\section{Éditeur :}

CNRS (UMR 7528 Mondes iraniens et indiens), Éditions de l'IFRI

\section{Édition imprimée}

Date de publication : 15 mai 2011

ISSN : 0240-8910

\section{Référence électronique}

Ève Feuillebois-Piérunek, «Écrits des Maitres soufis 2. Trois traités de Baghdadî et Semnânî. Traduction et présentation de Stéphane Ruspoli. Corbey, Arfuyen, 2008, 190 p. (Les Carnets spirituels) », Abstracta Iranica [En ligne], Volume 31 | 2011, document 247, mis en ligne le 11 octobre 2012, consulté le 28 septembre 2020. URL : http://journals.openedition.org/abstractairanica/39726 ; DOI : https://doi.org/ 10.4000/abstractairanica.39726

Ce document a été généré automatiquement le 28 septembre 2020.

Tous droits réservés 


\title{
Écrits des Maîtres soufis 2. Trois traités de Baghdadî et Semnânî. Traduction et présentation de Stéphane Ruspoli. Corbey, Arfuyen, 2008, 190 p. (Les Carnets spirituels)
}

\author{
Ève Feuillebois-Piérunek
}

1 Le présent volume aborde deux auteurs marquants qui, chacun à leur manière, ont poursuivi et développé l'enseignement de Najm al-dīn Kubrā: Majd al-dīn Baġdādī (1161-1219), principal compagnon et disciple de Kubrā, et 'Alā al-Dawle Semnānī (1261-1336), dont l'œuvre amorce une synthèse entre le soufisme d'Ibn 'Arabī et celui des Kubrawis. Les trois traités présentés abordent tous le thème du voyage spirituel, qui est ascension vers la Lumière divine, et celui, apparenté, du Guide intérieur en tant que prophète initiateur et archétype de l'Homme Parfait. Ils décrivent les étapes du cheminement vers l'unification (tawhìd) : les combats de l'âme, victime des passions et des illusions, les états mystiques assumés par les différents sens subtils (lațā'ef), puis, faisant suite à la mort du vieil homme, la reconstitution de l'homme de lumière, et enfin, les saintes contemplations et l'union amoureuse à Dieu.

2 Les traités ici présentés et traduits sont l'Epître du voyage spirituel (Risāla fi's-safar) de Majd al-dīn Baġdādī, l'Epître du dévoilement intérieur (Risāla fi'l-kašf) de Semnānī, où les différents plans du dévoilement sont classés en fonction de sa théorie des sens subtils, et le Traité de la Lumière divine (Risāla Nūriyya) du même, un exposé synthétique de l'itinéraire spirituel, inspiré de l'enseignement de Najm al-dīn Kubrā, et dont les sept étapes sont rythmées par le recours au hadith des Soixante-dix mille voiles. 
INDEX

Thèmes : 8. Soufisme

\section{AUTEURS}

\section{ÈVE FEUILLEBOIS-PIÉRUNEK}

Université Sorbonne Nouvelle - Paris 3 - Mondes iranien et indien 